\title{
PEMBERIAN HUKUMAN DALAM PERSPEKTIF PENDIDIKAN ISLAM
}

\author{
M. Wisnu Khumaidi \\ STIT Darul Fattah Bandar Lampung \\ wisnukhumaidi@gmail.com
}

\begin{abstract}
Education is a maturing process of learning a very complex learners systematically through a curriculum that is applied in the educational unit that is useful to explore the potential of students from various facets of the life of society, nation and state. To realize these goals much needed discipline and sense of responsibility in the learning process. Consistency discipline and sense of responsibility in the learning process, then the required methode or preventive measures, one such method is the provision of a penalty or punishment in educational units aimed accompany the learning process in order to achieve educational goals that had been expected. We need to know the substance rather than reward and punishment will not be separated in the educational process as well as the essence of good and bad are both always go hand in hand at the wheel of life. Therefore, punishment in the educational process must be in accordance with Islamic education that directs learners to always berakhlaqul karimah able to distinguish between good and bad behavior in daily life both in the school environment and society in general.
\end{abstract}

Keyword: punishment, reward

\begin{abstract}
ABSTRAK
Pendidikan merupakan proses pematangan pembelajaran peserta didik yang sangat komplek secara sistematis melalui kurikulum yang diterapkan di satuan pendidikan yang berguna untuk menggali potensi siswa dari berbagai aspek kehidupan untuk masuk ke dalam lingkungan masyarakat, bangsa dan negara. Untuk mewujudkan tujuan tersebut sangat dibutuhkan kedisiplinan dan rasa tanggung jawab dalam proses pembelajaran. Disiplin konsistensi dan rasa tanggung jawab dalam proses pembelajaran. Metode yang diperlukan atau langkah-langkah pencegahan, menjadi salah satu metode tersebut adalah pemberian hukuman pada satuan pendidikan yang bertujuan untuk mencapai tujuan pendidikan yang telah diharapkan. Perlu kita ketahui tentang substansi dari reward (hadiah) dan hukuman tidak akan dipisahkan dalam proses pendidikan serta esensi kebaikan dan buruk keduanya selalu berjalan seiring pada roda kehidupan. Oleh karena itu, hukuman dalam proses pendidikan harus sesuai dengan pendidikan Islam yang mengarahkan peserta didik untuk selalu berakhlaqul karimah yang mampu membedakan antara perilaku baik dan buruk dalam kehidupan sehari-hari baik di lingkungan sekolah maupun masyarakat pada umumnya.
\end{abstract}

Kata Kunci: Hukuman, hadiah 


\section{PENDAHULUAN}

Pendidikan merupakan proses pembelajaran pendewasaan peserta didik yang sangat kompleks sistematis melalui kurikulum yang diterapkan dalam satuan pendidikan yang berguna menggali potensi peserta didik, baik dalam ranah kekuatan spiritual keagamaan, pengendalian diri, kecerdasan, dan keterampilan-keterampilan yang dibutuhkan dalam kehidupan beragama, bermasyarakat, berbangsa dan bernegara.

Untuk mewujudkan tujuan tersebut perlu ditanamkan sikap disiplin dan tanggung jawab yang besar dalam proses pembelajaran. Konsistensi sikap disiplin dan rasa tanggung jawab dalam proses pembelajaran sangat diperlukan, maka diperlukan metode atau tindakan-tindakan preventif. Salah satu metode tersebut ialah pemberian hukuman atau punishment dalam satuan pendidikan yang bertujuan mengiringi proses pembelajaran agar tercapainya tujuan pendidikan yang telah diharapkan. Adapun proses pemberian hukuman harus sesuai dengan tingkat kesalahan peserta didik dalam melanggar tata tertib dalam satuan pendidikan.

Sebelum memberikan hukuman, perlunya pendidik memberikan sosialisasi ketika pra-pembelajaran kepada peserta didik, jika melanggar ketentuan yang telah ditentukan atau tata tertib satuan pendidikan, maka akan dikenakan sanksi. Bahwasannya tujuan daripada hukuman bukan memberikan nilai-nilai negatif atau kebencian yang disematkan terhadap peserta didik, akan tetapi bertujuan memberikan pelajaran agar nilai kedisiplinan merupakan prinsip kunci untuk meraih kesuksesan di masa depan.

Tulisan ini mengetengahkan tema pembahasan Pemberian Hukuman Dalam Perspektif Pendidikan Islam. Sedangkan metode penelitian yang dipakai adalah kajian pustaka yang menggabungkan antara teori-teori para pakar pendidikan dan hadits Nabi Muhammad $\rho$.

Menurut pendapat para pakar pendidikan, pengertian hukuman (punishment) sebagai berikut :

- Amien Danien Indrakusuma (1973), hukuman adalah tindakan yang dijatuhkan kepada anak secara sadar dan sengaja sehingga menimbulkan nestapa, dan dengan adanya nestapa itu anak akan menjadi sadar akan perbuatannya dan berjanji di dalam hatinya untuk tidak mengulanginya.

- Abdullah Nashih Ulwan (1999), hukuman ialah memberi pelajaran baik bagi si pelaku ataupun orang lain, semua itu adalah sebagai cara yang tegas dan tepat untuk memperbaikinya. 
- Elizabeth B. Hurlock (1978), Hukuman ialah : "Punishment means to inpose a penalty on a peron for a fault offense or violation or retaliation". Hukuman ialah menjatuhkan suatu siksa pada seseorang karena suatu pelanggaran atau kesalahan sebagai ganjaran atau balasannya.

- Abdurrahman Mas’ud (1999), hukuman dalam istilah psikologi adalah cara yang digunakan pada waktu keadaan yang merugikan atau pengalaman yang tidak menyenangkan yang dilakukan oleh seseorang dengan sengaja menjatuhkan orang lain. Secara umum disepakati bahwa hukuman adalah ketidaknyamanan (suasana tidak menyenangkan) dan perlakuan yang buruk atau yang jelek.

Berdasarkan pengertian diatas, hukuman disebabkan oleh adanya pelanggaran yang dilakukan oleh peserta didik. Jadi, pemberian hukuman yang dimaksud ialah memberikan suatu beban yang terkadang tidak menyenangkan yang mengandung unsur pendidikan, supaya anak tersebut jera dan berjanji tidak akan mengulangi perbuatan yang mengandung penyimpangan aturan. Sehingga anak benar-benar sadar dan mengerti, kemudian berusaha untuk memperbaiki atas perbuatan tidak terpuji yang telah diperbuat.

Secara umum, paling tidak terdapat 3 macam fungsi hukuman, yaitu untuk membatasi perilaku, bersifat mendidik, dan Memperkuat motivasi untuk menghindarkan diri dari tingkah laku yang tidak diharapkan.

Sebelum memberikan hukuman, perlunya pendidik memberikan sosialisasi ketika pra-pembelajaran kepada peserta didik, jika melanggar ketentuan yang telah ditentukan atau tata tertib satuan pendidikan, maka akan dikenakan sanksi. Bahwasannya tujuan daripada hukuman bukan memberikan nilai-nilai negatif atau kebencian yang disematkan terhadap peserta didik, akan tetapi bertujuan memberikan pelajaran agar nilai kedisiplinan merupakan prinsip kunci untuk meraih kesuksesan di masa depan.

A.L. Gary Gore dalam Suwarno (1992) berpendapat bahwa, anak-anak tidak boleh dididik dengan ketakutan. Janganlah dibina dengan paksaan-paksaan yang tidak mereka pahami. Seorang pendidik yang ingin memaksakan kehendaknya kepada anak-anak, secara tidak sadar sedang mengajarkan bahwa kebenaran itu (harus dilakukan) dengan paksaan. Efek negatif lain dari kekerasan yang diterima adalah anak-anak tidak melakukan pelanggaran karena takut akan hukuman bukan lahir dari kesadaran mereka. Sementara sifat buruknya tetap bersemayam di dalam dirinya. Hukuman tidak membawa kebaikan sama sekali bahkan merugikan. Rasa sakit itu akan masuk dalam memorinya. Masih ada orang tua yang sampai sekarang berpikiran bahwa anak-anak harus belajar sesuatu dengan 
pukulan, padahal anak-anak yang sering menerima kedisiplinan yang keras tersebut sebenarnya berusaha memerankan anak yang baik di depan mata orangtuanya, sementara jiwanya membelakangi mereka.

Oleh karena itu, dalam proses pemberian hukuman dalam dunia pendidikan menuai pro dan kontra dalam pengaplikasiannya. Contoh seperti pendapat Gary Gore diatas yang menyatakan ketidaksetujuannya dalam memberikan hukuman dalam pendidikan. anakanak tidak boleh dididik dengan ketakutan. Janganlah dibina dengan paksaan-paksaan yang tidak mereka pahami. Seorang pendidik yang ingin memaksakan kehendaknya kepada anak-anak, secara tidak sadar sedang mengajarkan bahwa kebenaran itu (harus dilakukan) dengan paksaan. Efek negatif lain dari kekerasan yang diterima anak-anak adalah anakanak tidak melakukan pelanggaran karena takut akan pukulan bukan lahir dari kesadaran mereka. Sementara sifat buruknya tetap bersemayam di dalam dirinya. Pukulan tidak membawa kebaikan sama sekali bahkan merugikan. Rasa sakit itu akan masuk dalam memorinya.

Lain halnya dengan pola Pendidikan Islam, bahwa memberikan hukuman kepada peserta didik itu diperbolehkan, dengan dasar dan syarat yang telah ditetapkan dan distandarkan oleh Nabi Muhammad $\rho$ dalam beberapa hadits. Pemberian hukuman akan diberikan dengan tahapan dari yang ringan dahulu. Ditambah lagi bahwa tidak semua hukuman itu berupa tindakan fisik. Pihak yang mendukung beralasan hukuman hanya sebagai langkah terakhir jika telah melalui beberapa tahapan-tahapan yang lain dalam proses pembelajaran peserta didik.

Dalam kajian ini, penulis akan memaparkan pemberian hukuman terhadapa peserta didik dalam proses pembelajaran satuan pendidikan yang sesuai kaidah-kaidah keislaman (al-Qur'an dan al-Hadits) dan menurut pendapat para pakar pendidikan yang lainnya.

\section{HUKUMAN MENURUT PENDIDIKAN ISLAM}

Nabi Muhammad $\rho$ berwasiat kepada umatnya, ketika muncul suatu permasalahan maka rujuklah kepada Al-Quran dan Al-Hadits agar kita tidak akan tersesat dalam mengarungi kehidupan di dunia ini.

Pada hakikatnya sifat manusia terdapat nilai baik dan buruk. Seperti kita ketahui dengan janji Allah I yang telah tertera dalam kitab suci-Nya, "Barangsiapa yang mengerjakan kejahatan, niscaya akan diberi pembalasan dengan kejahatan itu dan ia tidak mendapat pelindung dan tidak (pula) penolong baginya selain dari Allah." (QS: AnNisaa' | Ayat: 123). 
Secara logika dari statemen seperti itu, istilah hukuman tidak bisa dihilangkan dalam subtansi pendidikan karena hukuman selalu beiringan dengan hadiah (reward). Hadiah berfungsi sebagai memotivasi minat belajar peserta didik yang telah berprestasi sedangkan hukuman sebagai tindakan preventif peserta didik yang telah melanggar tata tertib pembelajaran dan minim terhadap minat belajar. Jika salah satu dihilangkan maka proses pembelajaran dalam satuan pendidikan tidak akan berjalan sebagaimana semestinya yang diharapkan, dikarenakan hadiah dan hukuman adalah suatu rangkaian atau kesatuan yang tidak bisa dipisahkan (sunnatullah).

Sebagaimana firman Allah I berfirman dalam surat Az-Zalzalah ayat 7 dan 8:

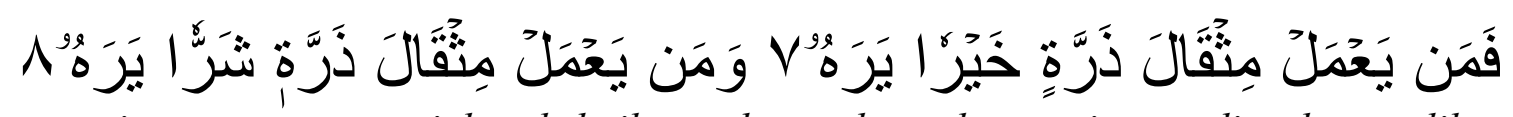
Barangsiapa yang mengerjakan kebaikan seberat dzarrahpun, niscaya dia akan melihat (balasan)nya. Dan barangsiapa yang mengerjakan kejahatan sebesar dzarrahpun, niscaya dia akan melihat (balasan)nya pula.

Berdasarkan surat az-Zalzalah, Allah I memberikan hadiah (surga) kepada hambanya yang semasa hidupnya di dunia melakukan kebaikan. Begitupun sebaliknya Allah I akan memberikan hukuman (neraka) kepada hambanya yang semasa hidupnya berbuat kebatilan. Substansi daripada hadiah dan hukuman tidak akan terpisahkan sama halnya dengan esensi nilai baik dan buruk yang keduanya selalu berjalan beriringan dalam kehidupan manusia.

Untuk menguatkan statement di atas, mari kita melihat suatu riwayat yang dimana Rasulullah $\rho$ memerintahkan umatnya agar mengajari anaknya yang ketika sudah berusia 7 tahun agar belajar salat, dan memerintahkan memukul jika anak sudah berusia 10 tahun enggan mengerjakan salat lima waktu. Nabi Nabi Muhammad $\rho$ menyampaikan :

Dari 'Abdullah bin 'Amr Radhiyallahu anhu , ia berkata, "Rasûlullâh Shallallahu 'alaihi wa sallam bersabda:

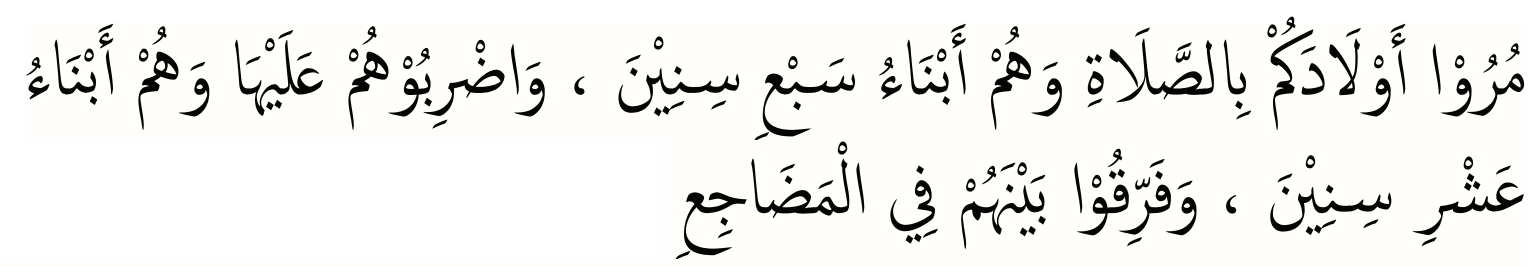

Suruhlah anak kalian shalat ketika berumur tujuh tahun! Dan pukullah mereka ketika berusia sepuluh tahun (jika mereka meninggalkan shalat)! Dan pisahkanlah tempat tidur mereka (antara anak laki-laki dan anak perempuan)!

Hadits ini hasan. Diriwayatkan oleh Abu Dawud, no. 495; Ahmad, II/180, 187; Al-Hakim, 
I/197; Dan al-Baghawi dalam Syarhus Sunnah, II/406, no. 505 dengan sanad hasan, dari 'Amr bin Syu'aib, dari ayahnya, dari kakeknya. Hadits ini dinyatakan sebagai hadits hasan oleh Imam an-Nawawi rahimahullah dalam al-Majmû' dan Riyâdhush Shâlihîn. Syaikh alAlbani rahimahullah berkata, "Sanadnya hasan shahih.” Lihat Shahîh Sunan Abi Dawud, II/401-402, no. 509.

Dari pemaparan hadits diatas, dapat diambil pengertian bahwa anak harus disuruh mengerjakan shalat ketika berusia tujuh tahun agar terbiasa menjalankannya dalam kehidupan sehari-hari, apabila anak tidak mengerjakan shalat, ketika sudah berusia 10 tahun, maka dikenakan hukuman pukul. Makna dari kata (pukullah) dalam hadits tersebut adalah memberikan pukulan tetapi tidak sampai meninggalkan bekas atau luka di tubuh agar tidak menimbulkan trauma yang berat bagi anak. Tujuan pemberian hukuman pukul sebagai tindakan preventif agar anak di usia 10 tahun akan tahu kewajiban untuk melaksanakan ibadah salat lima waktu sebagai bentuk penghambaan diri kepada Tuhan Yang Maha Esa.

Menurut Al-Ghazali, hukuman ialah suatu perbuatan dimana seseorang sadar dan sengaja menjatuhkan nestapa pada orang lain dengan tujuan untuk memperbaiki atau melindungi dirinya sendiri dari kelemahan jasmani dan rohani, sehingga terhindar dari segala macam pelanggaran. Hukuman adalah jalan yang paling akhir apabila teguran, peringatan dan nasehat-nasehat belum bisa mencegah anak melakukan pelanggaran.

Pemberian hukuman dengan cara memukul adalah tahap yang terakhir, setelah anjuran, peringatan dan lain-lain. Tata cara yang tertib ini menunjukkan bahwa pendidik tidak boleh menggunakan metode yang lebih keras jika yang lebih ringan sudah bermanfaat, sebab pukulan adalah hukuman yang paling berat dan tidak boleh menggunakannya kecuali jika tanpa ada jalan yang lain.

Abu Hasan al-Qabasyi, berpendapat bahwa seorang guru jangan menerapkan hukuman pukulan sehingga anak didik memperoleh adab (pendidikan) yang bermanfaat baginya. Kemarahan seorang guru tidak akan dapat menyembuhkan kemarahannya dengan memukul dan tidak pula menyenangkan hatinya dengan kekerasannya. Hukuman demikian tidaklah adil di mata anak didiknya. Ibnu Sachnun, menyarankan agar jangan memukul kepala atau muka anak, karena membahayakan kesehatan otak dan merusak mata atau berbekas buruk pada muka, sebaiknya pukulan hukuman diberikan kepada kedua kakinya, karena kali lebih aman dan lebih tahan untuk pukulan.

Dari beberapa uraian tentang pengertian hukuman tersebut, dapatlah penulis 
simpulkan bahwa yang dimaksud dengan hukuman dalam pendidikan, khususnya pendidikan Islam sebagai tindakan edukatif berupa perbuatan orang dewasa atau pendidik yang dilakukan dengan sadar pada anak didiknya dengan memberi peringatan dan pelajaran kepadanya atas pelanggaran yang telah diperbuatnya sesuai dengan prinsi-prinsip dan nilai-nilai keIslaman. Sehingga anak didik menjadi sadar dan menghindari segala macam pelanggaran dan kesalahan yang tidak diinginkan atau dengan berhati-hati dalam setiap melakukan perbuatan.

\section{TUJUAN HUKUMAN (PUNISHMENT)}

Hukuman merupakan salah satu media dari beberapa media pendidikan. Pendidikan tidak mungkin terpenuhi dengan penerapan satu metode saja, hal itu dikarenakan dinamika tabi'at manusia berbeda tingkatan dalam merespon pengaruh beberapa media pendidikan. Sebagian ada yang merespon dengan satu nasihat saja, atau dengan sekali motivasi atau satu kali ancaman. Sebagian ada yang merespon dengan berkali-kali nasihat, motivasi dan ancaman. Oleh karena itu, pemberian hukuman harus sesuai dengan tingkat pelanggaran yang dilakukan peserta didik. Hukuman yang diterapkan dalam proses pembelajaran harus mengandung unsur-unsur nilai yang positif yang akan diterapkan

Menurut Kartini Kartono, tujuan hukuman dalam pendidikan ialah :

1. Untuk memperbaiki individu yang yang bersangkutan agar menyadari kekeliruannya, dan tidak akan mengulanginya lagi.

2. Melindungi pelakunya agar dia tidak melanjutkan pola tingkah laku yang menyimpang, buruk dan tercela.

3. Sekaligus juga melindungi masyarakat luar dari perbuatan dan salah (nakal, jahat, asusila, kriminial, abnormal dan lain-lain) yang dilakukan oleh anak atau orang dewasa.

Berdasarkan penjelasan tujuan hukuman di atas, maka dapat diambil pengertian bahwa tujuan hukuman dalam pendidikan Islam untuk perbaikan kesalahan yang telah dilakukan anak- anak, bukan menjadikan sebuah ajang balas dendam dan pendidikan disini terlebih menganjurkan kepada para pendidik untuk mengenal akan perangai, tabi'at dan akhlak anak didiknya sebelum menjatuhkan hukuman. Sedangkan tujuan pokok hukuman dalam pendidikan Islam ialah pencegahan, pengajaran, melindungi dan pendidikan, arti pencegahan ialah menahan si pembuat kesalahan supaya tidak ikut-ikutan berbuat kesalahan kembali dan menjadikan pelajaran untuk peserta didik lainnya. 


\section{FUNGSI HUKUMAN DALAM PENDIDIKAN}

Hukuman merupakan salah satu media dan metode dalam proses pembelajaran yang berfungsi dalam ranah pendidikan memiliki tiga peran penting dalam perkembangan moral peserta didik. Adapun tiga peranan tersebut adalah sebagai berikut :

1. Mencegah, menghalangi perilaku-perilaku buruk tehadap peserta didik yang tidak sesuai dengan tata tertib pendidikan.

2. Mendidik, memahami perilaku-perilku yang mana mengandung nilai baik dan buruk.

3. Memberi motivasi untuk menghindari dari perilaku yang tidak sesuai dengan tata tertib pendidikan.

\section{SYARAT PEMBERIAN HUKUMAN}

Pemberian hukuman dalam proses pendidikan harus sesuai dengan kaidah tujuan pendidikan. Para pendidik harus memperhatikan betul terhadap perkembangan mental atau psikologis peserta didik yang pada saat itu akan terkena suatu hukuman. Dengan harapan para peserta didik lebih siap secara mental ketika akan menerima hukuman dari para pendidik. Para pendidik sebelum menjatuhkan atau memberikan suatu hukuman maka harus memahami persyaratan-persyaratan sebelum menjatuhkan suatu hukuman. Adapun syarat-syarat pemberian hukuman adalah sebagai berikut :

\section{Harus berdasarkan cinta, kasih, dan sayang}

Pemberian hukuman harus dilandasi sifat lemah lembut, kasih, dan saying. Seperti kita ketahui bersama, bahwa metode pemberian hukuman merupakan metode yang terpaling akhir atau metode yang terburuk dari sekian banyak metode yang lain. Oleh karena itu, janganlah sekali-kali peserta didik atau orang tua melayangkan tangannya secara langsung tanpa ada pertimbangan terlebih dahulu. Peserta didik sedapat mungkin menghindari metode hukuman dalam proses pembelajaran, jika melalui nasehat dan peringatan tidak ada perkembangan dalam proses pendidikan. Proses pemberian hukuman diberikan harus dilakukan secara cermat penuh kasih sayang yang bertujuan mengubah kebiasaan negatif ke perbuatan yang positif.

\section{Harus dalam keadaan darurat atau terpaksa}

Prinsip pokok dalam mengaplikasikan pemberian hukuman, yaitu bahwa hukuman adalah jalan yang terakhir dan harus dilakukan karena terpaksa atau darurat dan dimana dilakukan harus secara manusiawi. Agar tidak berdampak buruk terhadap kondisi 
perkembangan mental peserta didik. Penerapan suatu hukuman dapat dilakukan jika telah melalui penerapan dari beberapa metode yang lain terhadap peserta didik yang tidak ada perkembangan secara signifikan

\section{Harus mengandung makna edukasi}

Hukuman merupakan salah satu cara atau tindakan yang dilakukan para pendidik terhadap peserta didik baik berupa denda atau sanksi yang ditimbulkan akibat tindakan yang tidak sesuai dengan peraturan yang telah ditetapkan. Dengan tujuan peserta didik menyadari kesalahan yang telah diperbuat agar tidak mengulanginya lagi dan menjadikan anak itu baik sesuai dengan tujuan yang hendak ia capai.

Namun yang perlu diingat, bahwa hukuman harus bersifat edukasi (mendidik), dan memberitahu kesalahannya serta menyadarkan dan melatih anak-anak untuk tunduk serta patuh pada peraturan yang telah ditetapkan. Hukuman diberikan dengan maksud memperbaiki dan mendidik ke arah yang baik. Abdullah Nashih Ulwan menyatakan "diberikan kesempatan kepada anak didik untuk bertobat dari apa yang dilakukannya, memberi kesempatan untuk minta maaf dan untuk memperbaiki kesalahannya”.

Ada beberapa contoh sanksi mendidik yang sekaligus dapat dipergunakan oleh para pendidik untuk memberikan hukuman kepada siswa-siswa yang melanggar tata tertib pembelajaran. Sanksi-sanksi ini merupakan contoh sanksi mendidik yang tidak terlalu beresiko.

\section{a. Bermuka Masam}

Seorang guru dapat saja kadang-kadang bermuka masam di hadapan anak didiknya jika mereka berbuat kegaduhan, atau terhadap anak yang melakukan kesalahan dan melanggar peraturan. Tentu ini lebih baik daripada memukul atau menendang si anak, dengan cemberut atau bermuka masam secara psikologis sudah memukul perasaannya dan membuatnya malu dengan kawan-kawannya yang lain.

\section{b. Menegur Jika Siswa Bersalah}

Pada waktu anak melakukan suatu pelanggaran atau kesalahan alangkah lebih mendidiknya bila seorang guru menghukumnya dengan menegur. Menegur disini dimaksud adalah dengan kata-kata baik dan tertuju kepada dia yang melakukan kesalahan, bisa juga berbentuk kata-kata agak keras akan kelakuan yang salah yang dilakukannya. 


\section{c. Dilarang Mengikuti Pelajaran}

Melarang mengikuti pelajaran adalah hukuman yang ringan dan mendidik, misalnya ada anak yang terlambat datang ke sekolah, dia dihukum untuk tidak boleh ikut belajar pada jam pertama. Ini bentuk hukuman yang lebih menyentuh dan memberikan kesadaran jika ini tetap dilakukan dia akan rugi dengan sendirinya.

\section{d. Tidak Menyapa}

Dengan segala kemungkinan yang dimiliki seorang pendidik, ia hendaknya berpaling dari anak atau muridnya pada saat ia mengetahui anak atau muridnya itu berdusta atau melakukan kesalahan. Dengan guru berpaling, siswa akan merasa ia telah melakukan kesalahan

\section{Diberikan setelah anak didik mencapai usia 10 tahun}

Pada hakekatnya para pendidik enggan menghendaki pemberlakuan hukuman dalam pendidikan kecuali dalam keadaan terpaksa. Dalam pendidikan Islam batasan pemberian hukuman terhadap peserta didik ketika usia anak sudah menginjak 10 tahun, berdasarkan hadis nabi yang memerintahkan pemukulan terhadap anak jika usia sudah 10 tahun tidak mengerjakan salat lima waktu.

Abu Hasan al-Qabasyi, menganjurkan agar para pendidik tidak memukul anak lebih dari 10 kali dan sebaiknya hanya $3 \times$ pukulan. Pukulan lebih dari $3 \times$ didasarkan atas kadar pengetahuan anak. Yang penting tujuan hukuman dengan pukulan itu dapat menimbulkan rasa jera. Menghukum anak tidak benar jika didasarkan atas kemarahan. Ibnu Sachnun, menyarankan agar jangan memukul kepala atau muka anak, karena membahayakan kesehatan otak dan merusak mata atau berbekas buruk pada muka, sebaiknya pukulan hukuman diberikan kepada kedua kakinya, karena lebih aman dan lebih tahan untuk pukulan.

\section{Syarat Hukuman}

Dalam memberikan hukuman, perlunya pendidik diberi beberapa rambu-rambu dan syarat agar tidak berlebihan dalam melaksanakan hukuman. Ngalim Purwanto membagi syarat hukuman dalam proses pembelajaran sebagai berikut :

a. Dapat dipertanggungjawabkan

b. Bersifat memperbaiki

c. Tidak boleh bersifat ancaman atau pembalasan dendam 

d. Jangan menghukum pada waktu sedang marah
e. Harus diberikan dengan sadar dan sudah diperhitungkan atau dipertimbangkan
f. Dapat dirasakan anak sebagai penderitaan yang sebenarnya
g. Jangan melakukan hukuman badan
h. Tidak boleh merusak hubungan baik antara si pendidik dan anak didiknya
i. Guru sanggup memberi maaf setelah anak itu menginsafi kesalahannya.

\section{BATASAN HUKUMAN}

Adapun hukuman berupa fisik, Athiyah al-Abrasyi memberikan kriteria yaitu :
a. Pemukulan tidak boleh dilakukan pada anak didik dibawah umur 10 tahun
b. Alat pemukulnya bukan benda-benda yang membahayakan, misalnya lidi, tongkat kecil dan lain sebagainya.
c. Pukulan tidak boleh lebih dari tiga kali.
d. Hendaknya diberi kesempatan untuk tobat dari apa yang akan ia lakukan dan memperbaiki kesalahan yang pernah mereka kerjakan.

\section{JENIS HUKUMAN YANG DIPERBOLEHKAN}

Hukuman yang dapat diterapkan pada anak dapat dikategorikan menjadi beberapa bagian yaitu :

a. Hukuman bersifat fisik seperti menjewer telinga, mencubit dan memukul. Hukuman ini diberikan apabila anak melakukan kesalahan, terlebih mengenai halhal yang harus dikerjakan anak.

b. Hukuman verbal seperti memarahi, maksudnya mengingatkan anak dengan bijaksana dan bila para pendidik atau orang tua memarahinya maka pelankanlah suaranya.

c. Hukuman non verbal seperti menunjukkan mimik atau raut muka tidak suka. Hukuman ini diberikan untuk memperbaiki kesalahan anak dengan memperingatkan lewat isyarat. Seperti hadis Nabi $\rho$ :

"Kami diberitahu oleh al-Qa'naby, dari Malik dia berkata, Fadhl bin Abbas pernah dibonceng Rasulullah, lalu ada seorang wanita dari Khutsum meminta fatwa kepada beliau, pada waktu itu Fadhl memandangnya, begitu juga sebaliknya wanita itu memandang Fadhl, dan Nabi memalingkan muka ke lain pihak”. (H.R. Abu Daud). 
d. Hukuman sosial seperti mengisolasi dari lingkungan pergaulan agar kesalahan tidak terulang lagi dengan tidak banyak bicara dan meninggalkannya agar terhindar dari ucapan buruk. Berdasarkan hadis dibawah ini :

"Kami diberitahu oleh Abu Bakar bin Abi Syaibah, kami diberitahu oleh Ismail bin Ulaiyah dari Ayyub, dari Sa'id bin Jubair, bahwasannya tetangga Abdullah bin Mughaffal melempar dengan kerikil, lalu dilarang oleh Abdullah katanya: "bahwa rasul melarang orang yang membidik dengan kerikil (melempar dengan kerikil)”. Lalu ia tetap mengulanginya lagi, dan dikatakan kepadanya:"telah kukatakan padamu, bahwa Rasulullah melarang melempar dengan kerikil, tapi kamu masih tetap ngotot!, maka aku tidak akan mengajakmu berbicara (tidak menegur lagi)”. (H.R.Muslim)

Dari uraian diatas, tentang macam hukuman kiranya dapat disimpulkan bahwasanya hukuman itu dapat diterapkan dalam pendidikan, terutama hukuman yang bersifat pedagogis. Menghukum bilamana perlu dan jangan terus-menerus serta hindarilah hukuman jasmani atau badan jikalau benar-benar tidak terpaksa. Menghukum merupakan sesuatu yang "tidak disukai", namun perlu diakui bersama bahwa hukuman itu memang diperlukan dalam pendidikan karena berfungsi menekan, menghambat atau mengurangi bahkan menghilangkan perbuatan yang menyimpang dari ketetapan apa yang sudah ada.

\section{TAHAPAN PEMBERIAN HUKUMAN DALAM PENDIDIKAN ISLAM}

Dalam pemberian hukuman ada tahapan yang harus diperhatikan oleh pendidik, mulai dari yang teringan hingga akhirnya menjadi yang terberat, yaitu :

1. Memberikan nasehat dengan cara dan pada waktu yang tepat.

Yaitu dengan tidak memojokkan dan mengungkit-ungkit kekeliruannya dengan nasehat yang panjang lebar, karena dapat membuat anak menolak terlebih dahulu apa yang akan disampaikan. Pemilihan waktupun harus dipertimbangkan sehingga anak bisa enjoy menerima masukan.

2. Hukuman pengabaian, untuk menumbuhkan perasaan tidak nyaman dan teracuhkan di hati anak.

3. Hukuman fisik, sebagai tahap akhir dengan catatan bahwa hukuman fisik (pukulan) yang diberikan tidaklah terlalu keras dan menyakitkan. 


\section{HAL YANG DIHINDARI DALAM HUKUMAN}

Muhammad Jameel Zeeno mengungkapkan, pada saat guru atau pendidik terpaksa memberikan sanksi atau hukuman, ia sebaiknya dapat menghindari beberapa hal sebagai berikut :

1. Memukul wajah anak. Hal ini tidak jarang kita temui di masyarakat atau di rumahrumah tangga, juga di sekolah-sekolah, bahkan ada yang sampai pukulan tersebut mengenai mata ada telinga dan mengakibatkan indra anak terganggu. Oleh itu oleh para pemerhati pendidikan dan kesehatan ini satu hal yang sangat dilarang dan harus dihindari.

2. Terlalu keras, seorang pendidik yang keras pada saat memukul akan disebut oleh murid-muridnya sebagai seorang yang kasar dan zalim. Sebutan dan gelar demikian suatu tanda buruk dan ketidak senangan anak terhadap si guru. Nabi Muhammad $\rho$ mengatakan sesungguhnya pada kelemah lembutan ada kebajikan, inilah yang mestinya ditampilkan.

3. Kata-kata yang tidak pantas. Kata-kata yang tidak pantas adalah kata-kata yang buruk dan sangat menyakitkan psikologi seorang anak, bahkan ada anak yang mengatakan ia lebih baik dipukul daripada dikatakan dengan bahasabahasa yang buruk serta menyinggung perasaan.

Rasulullah $\rho$ menjelaskan tahapan bagi pendidik untuk memperbaiki penyimpangan anak, mendidik, meluruskan kebengkokannya, membentuk moral dan spiritualnya menjadi tujuh seperti yang terdapat dalam buku Pendidikan Anak Dalam Islam, yaitu menunjukkan kesalahan dengan :
a. Pengarahan
e. Memutuskan hubungan (boikot)
b. Ramah tamah
f. Memukul
c. Memberikan isyarat
g. Memberi hukuman yang membuat jera
d. Kecaman

\section{KEUNGGULAN DAN KELEMAHAN METODE HUKUMAN DALAM PENDIDIKAN}

Setiap metode pembelajaran terdapat sisi positif dan negatif. Begitu juga salah satu metode pemberian hukuman tidak terlepas dari istilah keunggulan dan kelemahan. Armai Arief mengatakan dampak positif dari hukuman antara lain :

1. Menjadikan perbaikan-perbaikan terhadap kesalahan murid. 
2. Murid tidak lagi melakukan kelahan yang sama.

3. Merasakan akibat perbuatannya sehingga ia akan menghormati dirinya.

Sementara dampak kelamahannya adalah apabila hukuman yang diberikan tidak efektif, maka akan timbul beberapa kelemahan antara lain :

1. Akan membangkitkan suasana rusuh, takut dan kurang percaya diri.

2. Murid akan merasa sempit hati, bersifat pemalas serta akan menyebabkan ia suka berdusta (karena takut dihukum)

3. Mengurangi keberanian anak untuk bertindak.

\section{DAMPAK NEGATIF DARI HUKUMAN}

M. Ngalim Purwanto mengatakan ada tiga dampak negatif dari hukuman, yaitu :

a. Menimbulkan perasaan dendam pada si terhukum. Akibat ini harus dihindari karena hukuman ini adalah akibat dari hukuman yang sewengan-wenang dan tanpa tanggung jawab.

b. Anak menjadi lebih pandai menyembunyikan pelanggaran. Ini bukanlah akibat yang diharapkan oleh pendidik.

c. Si pelanggar menjadi kehilangan perasaan salah, karena si pelanggar merasa telah membayar hukumannya dengan hukuman yang telah diterimanya.

Dalam buku yang lain Syaikh Jamil Zainu berpendapat bahwa dampak negatif dari hukuman fisik ada tujuh, yaitu :

a. Mengacaukan dan menghambat jalannya pelajaran bagi murid secara keseluruhan.

b. Guru dan murid akan terpengaruh ketika diberlakuknnya hukuman dan hal itu akan membekas pada keduanya secara bersamaan.

c. Adanya bekas yang merugikan pada diri murid yang terkena pukulan baik pada wajah, mata, telinga atau anggota badan lainnya.

d. Kesulitan pemahaman terhadap pelajaran bagi murid yang dihukum

e. Kesulitan yang akan dihadapi guru untuk mempertanggung jawabkannya di hadapan hakim, keluarga dan penyidik

f. Terbuangnya waktu murid untuk belajar dan mereka akan terpengaruh dengan apa yang tengah terjadi ketika pelajaran berlangsung

g. Hilangnya rasa saling memuliakan dan menghormati antar murid dan guru. 


\section{PENUTUP}

Hukuman tidak bisa dihilangkan dalam subtansi pendidikan karena hukuman selalu beiringan dengan hadiah (reward). Hadiah berfungsi sebagai memotivasi minat belajar peserta didik sedangkan hukuman sebagai tindakan preventif peserta didik yang minim terhadap minat belajar. Jika salah satu dihilangkan maka proses pembelajaran dalam satuan pendidikan tidak akan berjalan sebagaimana semestinya yang diharapkan, dikarenakan hadiah dan hukuman adalah suatu rangkaian yang tidak bisa dipisahkan (sunnatullah).

Dalam pendidikan Islam, metode hukuman adalah salah satu metode atau alternatif yang paling akhir setelah metode lainnya diterapkan. Itu pun harus sesuai dilakukan dengan cara, kadar dan situasi yang tepat. Dengan tujuan agar para peserta didik tidak akan mengulangi perilaku-perilaku buruk dalam proses pembelajaran yang tidak sesuai dengan tata tertib sekolah. Guru mengarahkan siswa selalu berakhlaqul karimah dan mampu membedakan perilaku baik dan buruk dalam kehidupan sehari-hari baik di lingkungan sekolah maupun masyarakat pada umumnya.

\section{DAFTAR PUSTAKA}

Abdullah Nashih Ulwan, 1999, Tarbiyatul Aulad fil Islam, terj. Jamaludin Miri, Pustaka Amani, Jakarta

Abdurrahman Mas'ud, 1999, Reward dan Punishment dalam Pendidikan Islam, Media, Edisi 28, Th. IV, Nopember

Abu al-Husain Muslim, Shahih Muslim, Bab Karoha al-Khadhaf, juz III, (BeirutLibanon: Daar al-Kitab al-Ilmiyyah, t. th)

Amien Danien Indrakusuma, 1973, Pengantar Ilmu Pengetahuan. Fakultas Ilmu Pendidikan IKIP Malang, Malang

Armai Arief, 2002, Pengantar Ilmu dan Metodologi Pendidikan Islam, Jakarta, Ciputat Pers

Elizabeth Bergner Hurlock, 1978, Child Development, Tokyo-Japan: Grawhill, Kogakhusa

Kartini Kartono, 1992, Pengantar Mendidik Ilmu Teoritis (Apakah Pendidikan Masih Diperlukan), Bandung: Mandar Maju

M. Ngalim Purwanto, 1994, Ilmu Pendidikan Teoritis dan Praktis, rev. ed.; Bandung, Remaja Rosda Karya

Muhammad Jamael Zaeno, 2005, Resep Menjadi Pendidik Sekses, Bandung, Kelompok 
Mizan

Syaikh Muhammad bin Jamil Zainu, 2005, Seruan Kepada Pendidik dan Orangtua, terj. Abu Hanan dan Ummu Dzakiyya, Solo 